Helgoländer wiss. Meeresunters. 24, 465-475 (1973)

\title{
In situ determination of primary production by means of a new incubator ISIS ${ }^{1}$
}

\author{
K. GUNDERSEN \\ Department of Microbiology, University of Hawaii; \\ Honolulu, Hawaii, USA
}

KURZFASSUNG: In-situ-Bestimmung der Primärproduktion mittels eines neuen Inkubators (ISIS). Die Notwendigkeit, Störungen des physikalischen, chemischen und biologischen Milieus während der Messung biologischer Vorgänge möglichst gering zu halten, hat zu der Konstruktion eines neuen, ISIS genannten und einfach zu handhabenden Inkubators zur Bestimmung der Primärproduktion in situ geführt. Eine ISIS-Einheit besteht aus einem Paar zylindrischer Kammern von 11 Volumen, die an einem zentralen Schaft befestigt werden, der die Führungen für Auslöser und Befestigung am hydrographischen Draht enthält. Die eine Kammer ist transparent, die andere ist lichtundurchlässig. Die Einheit wird mit geöffneten Kammern in das Wasser herabgelassen und nach einer Anpassungszeit durch Fallgewichte ausgelöst. Hierbei werden beide Kammern gleichzeitig durch Deckel von oben und unten verschlossen. Kurz, bevor die Deckel die O-Ringdichtung der Gefäße erreichen, wird eine am oberen Deckel befestigte Ampulle mit dem ${ }^{14} \mathrm{C}$ markierten Carbonat durch einen am unteren Deckel befestigten Stift zerbrochen; dabei wird die Lösung mit dem Wasser in den Behältern schnell vermischt. Der Draht mit den in verschiedenen Wassertiefen hängenden Inkubatoren wird dann an einer Boje oder unter einer Plattform befestigt; das Schiff ist während der Inkubationszeit für andere Zwecke frei. Nach der gewünschten Inkubationszeit wird das Gerät möglichst schnell an Bord geholt. Kleinere Proben werden in vorbereitete Flaschen mit Photosynthese-Inhibitoren abgefüllt und zur Filtration vorbereitet. Die Kohlenstofffixierung wird dann in der gewohnten Weise durchgeführt. Diese neue In-situ-Methode hat unter verschiedenen Versuchsbedingungen sehr präzise und reproduzierbare Resultate erbracht. Versuche, welche die Anwendbarkeit des Verfahrens im offenen Meer sowie in tropischen Aestuarien demonstrieren, werden beschrieben und diskutiert.

\section{INTRODUCTION}

Phytoplankton, like other organisms, respond to many variables in the environment. Changes may be stimulatory, such as added nutrients, or harmful, such as a sudden exposure to high light intensities. In any stable environment, each successful member of the biological community tends to occupy a niche in which, at any given time, the combined physical, chemical and biological parameters are optimal. Sudden changes induced in such a stable ecosystem may have unpredictable effects on its biological structure and function. The experimental ecologist, including the student of

${ }^{1}$ Contribution No. 399, Hawaii Institute of Marine Biology. 
primary production, is certainly aware of these problems and is continuously faced with the technical difficulties of observing without disturbing. Sources of error and limitations of the standard carbon-14 technique now used universally in aquatic photosynthetic productivity work have been discussed in detail by many workers (STEEMANN Nielsen \& Hansen 1959, JitTs 1963, Goldman et al. 1963, Strickland 1965).

It is well established that many phytoplankters may readily become damaged when suddenly exposed to high light intensities or to spectral ranges, particularly to ultraviolet and far red light, not existing at depth. Such damage may occur when a water sample is transferred to the surface and particularly during the filling of the BOD bottles prior to incubation. In addition, changes in temperature and hydrostatic pressure of the water sample may directly and indirectly disrupt the existing equilibrium of the microecosystem with unpredictable results. Moreover, the mere physical handling of water samples is known to be harmful to many delicate soft-bodied ultraplankters, particularly in tropical waters (DOTY 1955, STrRCKLAND 1965).

These various hazards are unavoidable in the currently used techniques for primary production determination in water bodies (STRICKLAND \& PARSONS 1968, VolLENWEIDER 1969). In spite of the general recognition of these shortcomings few seem to have attempted to improve on the technique. Dyson et al. (1965), working in Australia, built a twin light and dark sampler into which the radiocarbon solution could be directly injected, but only after retrieval of the sampler. In other words, the two sampling bottles served as experimental bottles thus avoiding the transfer of water from sampler to BOD bottles. The DYson instrument was either incubated in a constant temperature-light incubator on deck, or could be returned to depth for in situ incubation. Although this technique eliminated one of the hazards of the standard technique the potential light, temperature and pressure effects remained. An in situ instrument was described by WATT (1965) but, to my knowledge, it has never been used in primary production work. More recently, LEvin \& LINDGREN (1971) described a fully-automated, submersible instrument which not only will inject the carbon-14 solution into the water sample in situ but also filter and preserve the plankton at depth following incubation. The sophistication and cost of this instrument may be prohibitive for its general use in productivity work. A handy device described by HANEY (1971) for measurement of zooplankton grazing rates could probably be adapted to primary production work if equipped with a second, dark chamber.

I shall in this paper describe an in situ sampler-incubator which, by releasing the carbon-14 solution during the entrapment of the water sample, will eliminate most of the hazards of the conventional techniques. Its acronym, ISIS (In Situ IncubatorS), may be recognized as the Egyptian Goddess of Fertility!

\section{MATERIALS AND METHODS}

\section{Outline of the ISIS method}

The uniqueness of the ISIS-productivity method lies in its capacity to determine carbon dioxide uptake, and other biological activities, of a natural aquatic population 
of microscopic organisms without dislocating the organisms from their proper position within the water column or in any way, other than at will, introducing artificial physical or chemical changes in the water sample prior to or during the incubation period.

This is done by lowering a pair of open flushing bottles, one transparent to light, the other opaque, to a predetermined depth in the water column. When activated by a messenger, the two bottles will close simultaneously and, in the closing process, a glass ampule attached to one of the lids and containing the radioactive carbonate (or any other substrate) will break and release its content to the water in the bottles. The bottles will remain at depth for the duration of the incubation period. After recovery, subsamples are drained off and carbon utpake determined by conventional techniques.

\section{Description of ISIS}

Figure 1 shows an ISIS-unit with its two cylindrical bottles (1). One of the bottles is made of clear plastic (plexiglass or polycarbonate), called the light bottle (LB), the other made of opaque plastic (PVC), called the dark bottle (DB). The net volume of the individual bottles is $1000 \mathrm{ml} \pm 1 \%$.

Each bottle has the following features: The top and bottom lids (2), made of the same materials as the cylindrical parts, are hinged to an upper and a lower bottle support (3) cemented to the cylinders. The lid makes a tight fit with the cylinder by a silicone-rubber 0-ring (4) held firmly in place in a precisely machined groove in the lid. The upper lid has in the center a cylindrical ampule holder (5) with an elastic strap (6) holding the spherical ampule (7) in place. Further, the upper lid is equipped off-center with an air-vent (8). The lower lid has, in a central position, a cylindrical holder (9) for a glass-rod hammer (10) and, in an off-center position, a push-pull type draining valve (11).

The two lids are connected through two laterally positioned elastic straps (12) made of surgical rubber tubing. A glass ball (13) is inserted in the two end-openings of the tubing and prevented from escaping when the tubing is under tension by a string constriction. The straps are fitted in position in the lids through narrow slits (14). Finally, each lid is equipped with a looped strap (15) through which the lid can be cocked in an open position.

The two bottles are attached to a transparent plexiglass frame (16) by a pair of self-locking nylon pins (17). Bottles can readily be interchanged to form pairs of two $\mathrm{LB}$, two $\mathrm{DB}$, or one $\mathrm{LB}+$ one $\mathrm{DB}$, according to the need of the experiment.

The activation mechanism (not shown in detail in the figure) consists of a long stainless steel rod (18) which, at the upper end, is outfitted with a steel head (19), and below with two pairs of spring-loaded pin hooks (20) which, through the lid straps (15), hold the four lids in an open position.

The ISIS-unit is attachable to a $3 / 16^{\prime \prime}$ hydrographic cable (21), or a line, through an upper-end stainless steel clamp (22) and, at the lower end, an open spiral guide (23). When more than one ISIS-unit is used in a cast, a second messenger (24) can be attached to one of the lower-end release pins. 
When activated by a messenger, the four lids will close simultaneously with considerable force produced by the lateral rubber straps. When almost closed, the ampule will be shattered by collision with the hammer and the ampule content, helped by the turbulence created by the closing lids, will mix completely with the entrapped water sample within seconds.

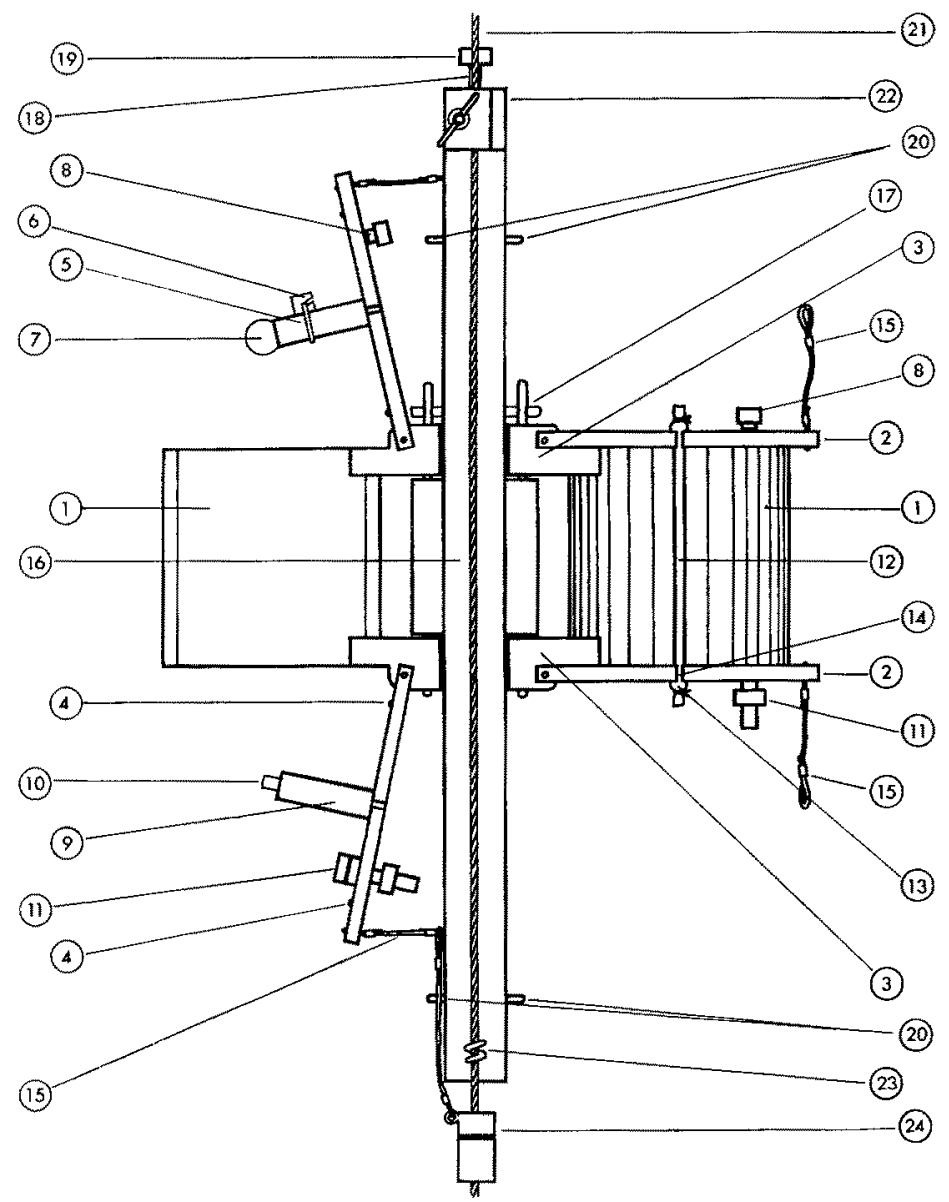

Fig. 1: Schematic description of an ISIS-unit. Number explanation in text

\section{Ampules and carbon-14 solutions}

The most suitable type of ampule for the ISIS-bottles was found to be a spherical type blown from pyrex glass (Fig. 2). The wall thickness of the bulb was about $1 / 10 \mathrm{~mm}$. For shallow water work ampules were sealed by melting in a burner (Type 1); for work at 10 atm hydrostatic pressure or more, an open-end ampule, sealed by melting a plug of paraffin wax on top of the carbonate solution, was found useful (Type 2). 
Various tests showed that an activity of 5 or $10 \mu \mathrm{c}$ of carbon-14 was suitable for use in moderately productive waters (fixation rates $5-50 \mathrm{mg} \mathrm{C} / \mathrm{m}^{3} / \mathrm{hr}$ ). In the oligotrophic type of oceanic water found off the Hawaiian Islands (fixation rates $<1 \mathrm{mg}$ $\left.\mathrm{C} / \mathrm{m}^{3} / \mathrm{hr}\right) 100 \mu \mathrm{c}$ gave reasonable results. One $\mathrm{ml}$ of carbon-14 labelled sodium carbonate in $5 \% \mathrm{NaCl}$ carrier solution was used with the ampule types described here. Mixing efficiencies, leakage testing, etc., were determined by using ampules with $1 \mathrm{ml}$ of a $0.1 \%$ methylene blue $-5 \% \mathrm{NaCl}$ solution.

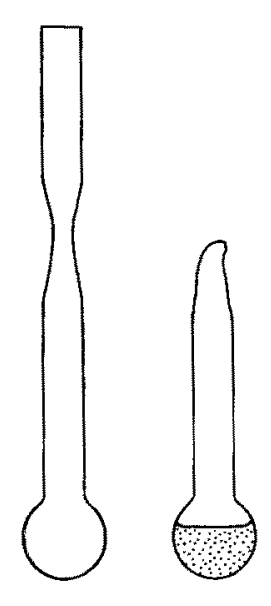

Type 1
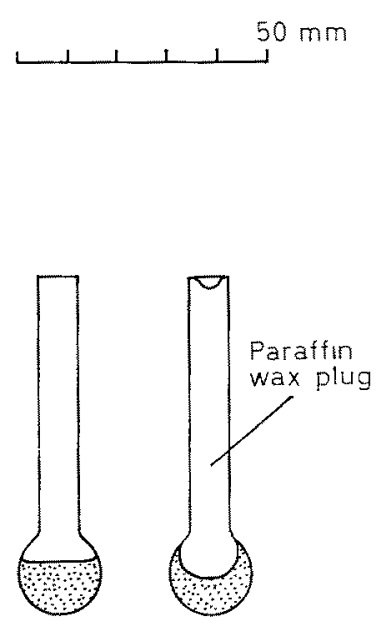

Type 2

Fig. 2: Two ampule types used in the ISIS-experiments

\section{Field methods}

All inshore work was done from a raft anchored in about $12 \mathrm{~m}$ deep water in Kaneohe Bay, a subtropical eutrophicated estuary on the northeast coast of Oahu, Hawaii. A simple wooden A-frame, approximately 4 by 1 by $2 \mathrm{~m}$, and a weightloaded rope, were used as support for the ISIS-units. Incubation times of $2 \frac{1}{2}$ to 5 hours were found satisfactory for productivity work at this eutrophic station.

Open ocean work was done from the University of Hawaii's $R / V$ Teritu at various stations off the leeward Hawaiian Islands Lanai and Oahu. To avoid shading from the ship during the incubation, the ISIS-units were suspended under a buoy carrying a $200-\mathrm{m}$ piece of weight-loaded hydrographic cable. After activation of the incubators (four units were used in each cast) the buoy was set adrift with a yellow flag as a marker. An incubation time of six hours (from 0900-1500 hours local time) was used in these experiments.

Sampling of water for alkalinity determination and for chlorophyll and nutrient analysis was made prior to the productivity casts using either ISIS-units without 
ampules as samplers or 13-1 PVC van Dorn-type water samplers. The methods used in the water analysis were basically those described by STrickland \& PArsons (1968).

Light measurements were made with a locally manufactured underwater color transmission meter read against a surface reference cell. The sensors were equipped with Corning neutral density and blue-green filters giving a maximal transmission at $462 \mathrm{~nm}$.

\section{Filtration and counting}

Following incubation, subsamples of $100-200 \mathrm{ml}$ were drained into $250-\mathrm{ml}$ erlenmeyer flasks or, in shipboard work, into $250-\mathrm{ml}$ polyethylene bottles containing $5 \mathrm{ml}$ of a $10^{-4} \mathrm{M}$ DCMU inhibitor (Good \& IzAw A 1965). Filtration was done in all-glass assemblies at a vacuum of about $200 \mathrm{~mm} \mathrm{Hg}$. The filters were $25 \mathrm{~mm}$ Millipore membrane filters of porosity $0.45 \mu \mathrm{m}$. The filter pads with precipitate were stored in loosecapped scintillation vials in a desiccator under vacuum for at least 48 hrs before counting.

The counting was done in a Packard Modell 3320 Tri-carb Scintillation Spectrometer using a toluene-base fluor containing $0.4 \%$ naphthalene, $0.4 \% \mathrm{PPO}$, and $0.04 \%$ POPOP.

\section{Decontamination of equipment}

Each ISIS-unit was supported during the draining of subsamples by a sturdy semi-open plywood box with a spill-tray. These supports were made water-tight and washable in acid by several coats of polyester resin. All radioactive spills were collected in a large polyethylene carboy. The ISIS-bottles, detached from the frame one at a time, were soaked and scrubbed in $1 \%$ hydrochloric acid in a $25-1$ bucket, followed by a thorough water rinse. All other contaminated equipment was given the same treatment which was found to be fully efficient in removing radioactive contamination.

\section{RESULT'S AND DISCUSSION}

\section{Productivity in shallow eutrophic water}

These experiments were made in Kaneohe Bay at three standard depths, 0.5, 5.5, and $10.5 \mathrm{~m}$. In the first experiment to be reported here primary production was compared to underwater light transmission and to the vertical distribution of nitrate. The ISIS-units were incubated for 6 hours between 0900-1500 hours using a LB-DB combination at each depth. The carbon -14 activity was $10 \mu \mathrm{c}$ per bottle. The results of this experiment are summarized in Table 1.

Whereas the light transmission was found to be fairly linear with depth, carbon fixation was not. As judged from the relatively high fixation rate at $5.5 \mathrm{~m}$ depth, a somewhat higher productivity near the surface was expected. Two immediate explanations of this observation could be that the production at $0.5 \mathrm{~m}$ was nutrient limited or that light inhibition took place. 
Table 1

Carbon fixation, light transmission, and nitrate in Kaneohe Bay

\begin{tabular}{|c|c|c|c|c|c|c|}
\hline \multirow{2}{*}{$\begin{array}{l}\text { Depth } \\
(\mathrm{m})\end{array}$} & \multirow{2}{*}{$\begin{array}{c}\text { Light } \\
\text { (\% of surface) }\end{array}$} & \multirow{2}{*}{$\begin{array}{l}\text { Nitrate } \\
(\mu \mathrm{g}-\mathrm{at} / 1)\end{array}$} & \multicolumn{4}{|c|}{ Carbon fixed $\left(\mathrm{mg} / \mathrm{m}^{3} / \mathrm{hr}\right)$} \\
\hline & & & LB & $\mathrm{DB}$ & $\mathrm{LB}-\mathrm{DB}$ & of $0.5 \mathrm{~m}$ \\
\hline 0.5 & 90 & 0.48 & 22.95 & 0.61 & 22.34 & $100 \%$ \\
\hline 5.5 & 11 & 0.16 & 8.09 & 0.29 & 7.80 & $35 \%$ \\
\hline 10.5 & 1.3 & 0.51 & 0.70 & 0.40 & 0.30 & $1.3 \%$ \\
\hline
\end{tabular}

To check the first possibility, carbon fixation was again measured at $0.5 \mathrm{~m}$ depth with simultaneous nitrate enrichment. Previous studies by CAPERoN et al. (1971) have shown that nitrogen rather than phosphorus is the limiting nutrient in Kaneohe Bay. This was done by using two ISIS-units, one composed of two $\mathrm{LB}$, the other of two DB. The individual bottles were equipped with the usual $10 \mu \mathrm{c}$ carbonate ampule in the upper lid. In situ nitrate enrichment was accomplished by further furnishing one of the bottles in each unit with an ampule containing $1 \mathrm{ml}$ of a $50 \mu \mathrm{g}$-at $\mathrm{NaNO}_{3}-$ solution in the lower lid. In the closing, both ampules were broken on impact and at the same time released the carbonate and the nitrate into the water sample.

The nitrate enrichment failed to stimulate carbon fixation in the LB as well as in the DB. Most likely, therefore, the relatively lower fixation observed near the surface was a result of light inhibition. CAPERON et al. (1971), who used the deck incubation technique during their study of productivity in this bay, observed that carbon fixation was somewhat inhibited if the bottles were incubated in full sunlight rather than with light filters.

In the following experiment, which in most respects was identical to the previous, carbon fixation was measured against chlorophyll a distribution ir this shallow water column. The results are shown in Table 2.

Table 2

Carbon fixation, chlorophyll $a$ and productivity index (mg C fixed/hr/mg chlorophyll a) at a Kaneohe Bay station

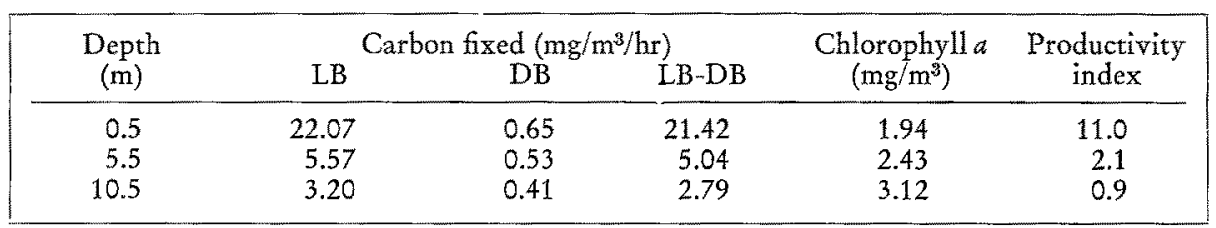

Although in this experiment the fixation rate at $0.5 \mathrm{~m}$ was nearly identical to the previous experiment, a somewhat lower rate was found at $5.5 \mathrm{~m}$ and a higher rate near the bottom $(10.5 \mathrm{~m})$. These inconsistencies are believed to reflect fluctuations in nutrient composition and heterogeneous distribution of organisms due to an irregular mixing pattern. Nutrient analyses made at various times in the water column support this belief. The variations in light and dark fixation with depth in two identical experiments at the Kaneohe Bay station are shown in Table 3. 
Table 3

Comparison of two ISIS experiments (IP-7 and IP-13) showing the relative distribution of carbon fixation with depth and dark fixation as percentage of gross light fixation

\begin{tabular}{|c|c|c|c|c|c|c|}
\hline \multirow{2}{*}{$\begin{array}{l}\text { Depth } \\
\text { (m) }\end{array}$} & \multicolumn{2}{|c|}{ LB-DB } & \multicolumn{2}{|c|}{$\mathrm{DB}$} & \multicolumn{2}{|c|}{$\mathrm{DB} \times 100 / \mathrm{LB}$} \\
\hline & IP-7 & IP-13 & IP-7 & IP-13 & IP-7 & IP-13 \\
\hline 0.5 & $100 \%$ & $100 \%$ & $100 \%$ & $100 \%$ & $3 \%$ & $3 \%$ \\
\hline 5.5 & $35 \%$ & $25 \%$ & $47 \%$ & $84 \%$ & $4 \%$ & $10 \%$ \\
\hline 10.5 & $2 \%$ & $13 \%$ & $65 \%$ & $63 \%$ & $58 \%$ & $13 \%$ \\
\hline
\end{tabular}

\section{Productivity in the open ocean}

Figure 3 shows the results of two casts made within the depth range $10-150 \mathrm{~m}$ at a station approximately $5 \mathrm{~km}$ off the leeward coast of Oahu. The two casts were made in the daytime on two successive days of roughly identical light and sea conditions.

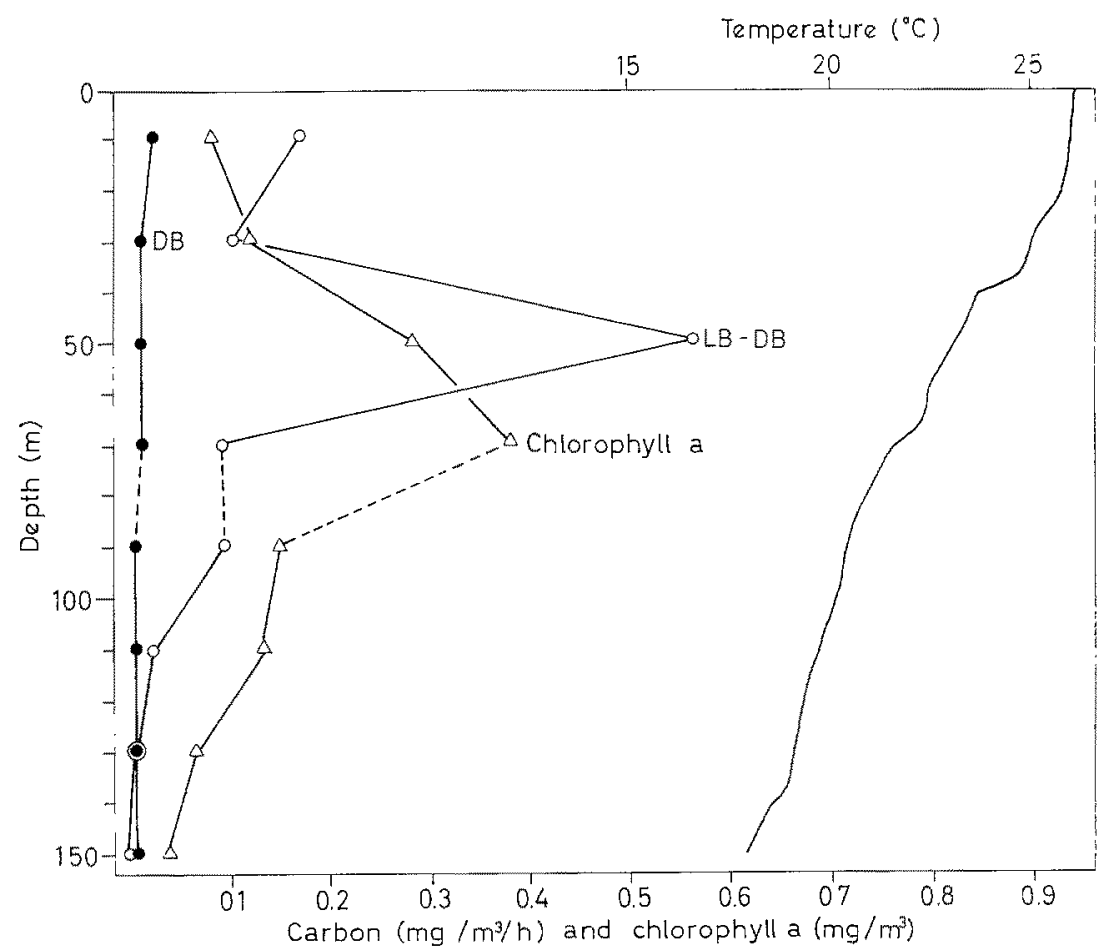

Fig. 3: ISIS-productivity, chlorophyll $a$, and temperature at an oceanic station off Oahu, Hawaii

Four ISIS-units of the usual LB-DB combination were used in each cast and the incubation lasted for six hours (0900-1500) under a drifting buoy. Wax-sealed ampules of $100 \mu \mathrm{c}$ carbon-14 activity were used in all bottles. Temperature (XBT), alkalinity, and chlorophyll $a$ determinations were made in connection with each cast. 
The absolute fixation rates at this oligotrophic station were rather low, but not lower than could be expected (STRICKLAND 1965). A fairly good correlation between chlorophyll a distribution and primary production was found. A productivity index of about 2 was calculated at $10 \mathrm{~m}$ and $50 \mathrm{~m}$ depth, whereas at $30 \mathrm{~m}$ the index was about 1 , indicating stratification of primary producers within the water column. A measurable net photosynthetic production as deep as $110 \mathrm{~m}$ was no surprise as previous light measurements in these waters (GUNDERSEN \& HANSON, in preparation) have shown that the $1 \%$ light level may occur as deep as $150 \mathrm{~m}$. This is also the depth at which phosphate and nitrate begin to appear in the water column.

\section{Advantages and disadvantages of the ISIS technique}

Although this new in situ technique for measuring primary production has eliminated most of the hazards connected with the pretreatment of water samples required by the standard techniques, one may argue that a true in situ condition has still not been achieved. What remains is the bottle wall, an environmental artefact which prevents chemical and biological interchange between the sample and the surrounding water mass. Moreover, solid surfaces may also adsorb ions and dissolved matter from the water and serve as a substratum onto which planktonic organisms may settle. Although we know that bacteria and diatoms settle within minutes on glass slides immersed in sea water, little is known about the effects of solid surfaces on primary production. Presumably, the measureable effect is small in exposures of only a few hours' duration, such as is practice in productivity work.

The surface effect can, on the other hand, be minimized by increasing the size of the water-enclosing vessel, but other considerations, such as the requirement for increasing amounts of radioactive carbon and the decreasing efficiency of mixing of the added substrate with the water sample, set a limit to the size of the bottle. The ISISbottles used in this study hold close to 11 and have a surface/volume ratio of about 0.6 whereas a standard BOD-bottle with a volume of $300 \mathrm{ml}$ has a surface/volume ratio of about 0.8 . If a roughly iso-diametric bottle were made to hold 21 , the surface! volume ratio could be brought down to about 0.45 . The effect of solid surfaces on primary production as measured by the carbon-14 method deserves a more detailed study.

When the ISIS-bottles are used at some depth it is unavoidable that excess internal hydrostatic pressure will force out some of the water as the bottles are pulled up towards the surface. Within 100 meters, probably the maximum depth at which the incubators will be used in productivity work, the volume of lost water will be of the order of $0.5 \mathrm{ml}$, an amount which could hardly produce any environmental hazard.

The advantage of the deck-incubation technique is that it permits the determination of primary production on a ship in transit. The ISIS technique and the standard in situ techniques do not permit this. But, at least a ship need not be tied up during the entire incubation period, as the bottles can easily be suspended under a buoy and set adrift thus saving expensive shiptime. In our open ocean experiments it took less than 15 minutes to complete the operation of attaching four ISIS-units to a $200-\mathrm{m}$ cable 
(deepest unit $150 \mathrm{~m}$ ), transfer the cable to the buoy and launch the buoy, and a similar length of time was required for the recovery operation.

The obvious advantage of the ISIS-technique is that it offers the closest possible approach to in situ incubation. It eliminates the need for a deck incubator, light filters, cooling arrangements, etc. The ISIS-bottle can also be used as a regular water sampler (without ampule) for taking an initial sample for $\mathrm{pH}$, alkalinity, salinity, chlorophyll, and nutrient analysis, and the volume of each bottle is large enough to permit the filtration of several subsamples for carbon uptake determination. The simultaneous determination of productivity at several depth levels can be accomplished with ease and is considerably less time consuming than any of the standard techniques. The interchangeability of bottles and the possibility of using two ampules at a time makes the ISIS technique applicable to experimental ecological work of many kinds.

\section{SUMMARY}

1. A new sampler-incubator, ISIS, is described which, by feeding a solution of carbon14-carbonate into the sample at the moment of sampling, permits a true in situ determination of primary production in a water body.

2. Several experiments, which exemplify the ISIS technique, are described in detail.

3. The advantages and disadvantages of the new and current standard techniques for measuring primary production are discussed.

Acknowledgements. The author is indebted to Mr. R. L. Richards, Honolulu, for solving the technical problems of the ISIS concept and to Mr. J. KaHL, Kahl Scientific Instrument Corp., San Diego, California, USA, for building the ISIS-units used in this study. The interested participation of several graduate students, and officers and crew of the R/V Teritu, in this work is equally acknowledged. The research was supported by National Science Foundation grant GA 27288 in biological oceanography.

\section{LITERATURE CITED}

Caperon, J., Cattelle, S. A. \& Krasnick, G., 1971. Phytoplankton kinetics in a subtropical estuary: eutrophication. Limnol. Oceanogx. 16, 599-607.

DotY, M. S., 1955. Current status of carbon-14 method of assaying productivity of the ocean. Rep. Congr. atom. Energy Commn U. S., Contr. At (04-3)-15.

Dyson, N., JitTs, H. R. \& ScotT, B. D., 1965. Techniques for measuring oceanic primary production using radioactive carbon. Ted. Pap. Div. Fish. Oceanogr. C.S.I.R.O. Aust. 18, 1-12.

Goldman, C. R., Mason, D. T. \& Wood, B. J. B., 1963. Light injury and inhibition in Antarctic freshwater phytoplankton. Limnol. Oceanogr. 8, 313-322.

Good, N. E. \& IzAWA, S., 1965. Selective inhibitors of photosynthesis. In: Biochemical dimensions of photosynthesis. Ed. by D. W. Krocmann $\&$ W. H. Powers. Wayne State Univ. Press, Detroit, 62-73.

HANEY, J. F., 1971. An in situ method for the measurement of zooplankton grazing rates. Limnol. Oceanogr. 16, 970-977.

JrTrs, H. R., 1963. The simulated in situ measurement of oceanic primary production. Aust. J. mar. Freshwat. Res. 14, 139-147. 
LEVIN, G. V. \& LINDGREN, W. A., 1971. APPI - automatic primary productivity instrument. Proc. 7 th ann. mar. techn. Soc. Conf., 671-680.

SteEmann Nreisen, E. \& Hansen, V. K, 1959. Light adaptation in marine phytoplankton and its interrelation with temperature. Physiologia Pl. 12, 353-370.

Strickland, J. D. H., 1965. Production of organic matter in the primary stages of the marine food chain. In: Chemical oceanography. Ed. by J. P. Rilex \& G. Skrrrow. Acad. Press, London 1, 447-610.

- \& Parsons, T. R., 1968. A manual of seawater analysis. Bull. Fish. Res. Bd Can. 125, 1-203.

VOLLENWEIDER, R. A. (Ed.), 1969. A manual on methods for measuring primary production in aquatic environments, including a chapter on bacteria. Blackwell, Oxford. 1-213.

WATT, W. D., 1965. A convenient apparatus for in situ primary production studies. Limnol. Oceanogr. 10, 298-300.

Author's address: Professor K. Gundersen

University of Hawaii

Department of Microbiology

Honolulu, Hawaii 96822

USA 